\title{
Mindre smerte ved lokalbedøvelse
}

\author{
Smerte ved lokalbedøvelse anses ofte som et nødvendig onde, men kan \\ reduseres ved hjelp av enkle tiltak.
}

Stadig flere og større kirurgiske inngrep foretas i lokalbedøvelse. For pasienten er det ved mindre inngrep ofte selve administrasjonen av lokalbedøvelsen som er mest smertefull. Smerten skyldes stikket gjennom huden, at væskeinfiltrasjonen aktiverer reseptorer $\mathrm{i}$ det dypere vevet som stimuleres av strekk, og den kjemiske sammensetningen av den injiserte væsken.

Mindre smerte i forbindelse med selve bedøvelsen er mulig. Det er ingen grunn til $i k k e$ å fjerne eller redusere den sviende og sprengende følelsen hos pasienten. Dette kan oppnås med enkle midler - særlig viktig ved behandling av barn.

\section{Bufring}

Bufring av lidokain med natriumbikarbonat $0,5 \mathrm{mmol} / \mathrm{ml}$ i forholdet 9:1 er vanligste måte å redusere injeksjonsmerter på. Lidokain selges i en sur oppløsning fordi det gir lengre holdbarhet, men lav $\mathrm{pH}$-verdi stimulerer nociseptorer i vevet. Ved å bufre oppløsningen kan $\mathrm{pH}$-verdien økes fra omkring 6,55 til 7,30 (1). Dette reduserer holdbarheten, men oppløsningen kan fortsatt oppbevares i omkring en uke i romtemperatur uten at virkningen av lidokainen nedsettes (2).

I en metaanalyse fra 2009 ble 12 studier vurdert. Konklusjonen var at høyere $\mathrm{pH}$ verdi i lidokain gir mindre smerte ved injeksjon (3). I en nyere studie fikk 32 frivillige injisert $4,5 \mathrm{ml}$ av både bufret og ubufret lidokain i subkutant fett på magen (1). 20 av dem syntes at den bufrede oppløsningen gjorde minst vondt, mens åtte foretrakk den ubufrede.

Lidokain med adrenalin er surere enn ren lidokain. Dersom dette brukes, er det derfor sannsynligvis enda større grunn til å bufre. Virkningen av adrenalinet $i$ oppløsningen vil da blir redusert med $25 \%$ per uke (4).

Bufring er svært lite tidkrevende hvis ampuller med natriumbikarbonat rutinemessig oppbevares sammen med lidokainet. Om man bruker små mengder lidokain hyppig, er det praktisk å fjerne $2 \mathrm{ml}$ fra $20 \mathrm{ml}$-glasset og tilsette det $2 \mathrm{ml}$ natriumbikarbonat 0,5 $\mathrm{mmol} / \mathrm{ml}$. Ved behov for en større mengde lokalbedøvelse kan man i en 20 ml-sprøyte først trekke opp $2 \mathrm{ml}$ natriumbikarbonat i sprøyten og deretter fylle den med lidokainoppløsning.

\section{Oppvarming}

I en litteraturoversikt ble det konkludert med signifikant mindre smerte ved bruk av lidokain oppvarmet til kroppstemperatur enn ved bruk av romtemperert løsning (5). Dette gjaldt både ubufret og bufret lidokain.

I en nylig publisert norsk studie fikk 36 frivillige tre injeksjoner à $4,5 \mathrm{ml}$ ubufret lidokain subkutant på magen (6). Den ene injeksjonen holdt kjøleskapstemperatur, den andre $\mathrm{Ni}$ deltagere foretrakk kjøleskapskald lidokain, ni den romtempererte, mens 17 mente oppvarmet lidokain ga minst smerter.

Lidokainets løselighet øker ved stigende temperatur (7). Det er mulig dette gjør at midlet virker raskere. Lidokain kan varmes til $70^{\circ} \mathrm{C}$ uten å bli ødelagt (8). Oppvarming kan enkelt gjøres ved å sette glasset $\mathrm{i}$ en vanlig tåteflaskevarmer før væsken trekkes opp (6).

\section{Injeksjonshastighet}

Litteraturen er ikke entydig når det gjelder sammenhengen mellom injeksjonshastighet og smerte. Det har vært foreslått at langsom injisering reduserer distensjonen av vevet fordi den injiserte væsken får bedre tid til å diffundere inn i omkringliggende vev, og at de frie nerveendene får tid til å tilvenne seg det økte trykket og derfor aktiveres mindre (4).

I to studier fant man at langsom injeksjonshastighet $-0,03 \mathrm{ml} / \mathrm{s}$ - var signifikant mindre smertefullt enn rask injeksjon (9, $10)$, mens i en tredje studie var det ingen forskjell (11). I alle de tre studiene ble det injisert 1-2 $\mathrm{ml}$. Den langsomme injeksjonen varte 6-10 ganger lenger enn den raske.

I en nylig publisert studie fikk 36 frivillige tre injiseringer med $4,5 \mathrm{ml}$ ubufret lidokain i subkutant fettvev på magen i løpet av 15 sekunder, 30 sekunder og 45 sekunder (12). Åtte foretrakk rask injeksjon, 15 den mellomste hastigheten og ti den langsomste. Forskjellene var ikke statistisk signifikante.

Det vil ikke være klinisk gjennomførbart i alle situasjoner å forlenge injeksjonstiden med en faktor på 6-10. For eksempel tar det 150 sekunder å injisere $4,5 \mathrm{ml}$ med en hastighet på $0,03 \mathrm{ml} / \mathrm{s}$. Ofte vil ikke kirurgen ha tålmodighet til å bruke så lang tid på injeksjonen, særlig hvis det skal injiseres større mengder lokalbedøvelse. Det er neppe tilromtemperatur og den tredje omtrent $38^{\circ} \mathrm{C}$.

\author{
Vilhjalmur Finsen \\ vilh@finsen.no \\ Det medisinske fakultet \\ Norges teknisk-naturvitenskapelige universitet \\ og \\ Ortopedisk avdeling \\ St. Olavs hospital \\ Engelsk oversettelse på www.tidsskriftet.no \\ HOVEDBUDSKAP
}

Smerte ved injeksjon av lidokain kan reduseres

Bufring og oppvarming av lidokainoppløsningen før injeksjonen er sannsynligvis de enkleste og mest effektive tiltakene

Penetrasjon av huden i $90^{\circ}$ vinkel og bruk av tynne kanyler kan også gi mindre smerte 
rådelig å injisere svært raskt, men ellers synes injeksjonshastigheten å være av underordnet betydning for opplevelsen av smerte.

\section{Kanyletykkelse}

I de fleste studier der man har sett på forholdet mellom smerte og kanyletykkelse, har man undersøkt injeksjon av svært små volumer med svært tynne kanyler, slike som brukes ved vaksinasjoner, tromboseprofylakse, insulininjeksjoner og lignende. Man finner at tynnere kanyler (30 gg og 32 gg) gjør mindre vondt, men disse studiene har sannsynligvis begrenset relevans for den aktuelle problemstillingen. Det er likevel interessant at Palmon og medarbeidere, som injiserte $0,25 \mathrm{ml}$ ubufret eller bufret lidokain gjennom $25 \mathrm{gg}$ eller 30 gg kanyler, konkluderte at bufringen hadde større betydning for provokasjon av smerte enn kanyletykkelsen (13).

I en klinisk studie med 84 pasienter ble det imidlertid funnet at ved lokalbedøvelse før spalting av karpaltunnel med enten $23 \mathrm{gg}$ kanyle eller 27 gg kanyle var det signifikant mindre smerte med tynne kanyler (14). I en senere studie ble $3 \mathrm{ml}$ ubufret lidokain injisert subkutant på magen til 36 frivillige med kanyler med tykkelse $0,8 \mathrm{~mm}$ (grønn, $21 \mathrm{gg}$ ), $0,6 \mathrm{~mm}$ (blå, $23 \mathrm{gg}$ ) og 0,4 mm (grå, $27 \mathrm{gg}$ ) (15). Deltagerne ble bedt om å vurdere hele prosedyren, ikke bare stikket. 21 bedømte at injeksjon med den tynneste kanylen var minst smertefull, seks foretrakk den mellomste kanylen og syv den tykkeste, mens to hadde ingen bestemt mening.

Det virker således tilrådelig å velge en tynn kanyle dersom man ikke skal injisere store mengder lidokain. I vanlig skadekirurgi og ortopedisk kirurgi vil dette vanligvis bety en 27 gg-kanyle. Ut fra litteraturen kan man likevel få det inntrykk at virkningen av dette er mindre enn virkningen av å varme lidokainen og å bufre den. Dersom det skal injiseres en stor mengde, kan det være akseptabelt å benytte kanyler på 23 gg eller 25 gg.

\section{Andre tiltak}

En kanylevinkel gjennom huden på $90^{\circ}$ gir minst smerte, fordi kanylen da treffer færrest smertereseptorer $(4,16)$. Også det å klype, klemme eller strekke huden nær der man skal injisere kan redusere smerten, muligens fordi nerveimpulsene dette provoserer, "stenger» for smerteimpulsene $(4,17)$.

Nedkjøling av området som skal bedøves med isbiter i 2-5 minutter reduserer injeksjonssmerten. Leff og medarbeidere (18) randomiserte 100 pasienter som skulle gjennomgå operasjon av inguinalhernie i lokalbedøvelse. Halvparten holdt en ispose med temperatur $4{ }^{\circ} \mathrm{C}$ mot operasjonsområdet $\mathrm{i}$ fem minutter før bedøvelsen. Dette reduserte gjennomsnittlig smerteskår ved bedøvelsen fra $6 / 10$ til 2/10. Hvordan nedkjøling reduserer smerte i denne sammenhengen er uklart, men det er foreslått at karkonstriksjon og nedsatt ledningsevne i de nærliggende nervene er av betydning $(4,17,18)$.

Applikasjon av Emla krem (en kombinasjon av lidokain og prilokain) er nyttig før dermatologiske inngrep og venepunksjon (4). Bedøvelsen når imidlertid bare $3 \mathrm{~mm}$ ned i vevet etter 60 minutter, det vil derfor være upraktisk å bruke slik krem før lokalbedøvelse med infiltrasjon. I en studie fikk 20 pasienter $0,1 \mathrm{ml}$ lidokain med adrenalin injisert gjennom en $30 \mathrm{gg}$ kanyle etter at injeksjonsstedet først var behandlet med Emla krem i 52 minutter eller med is i 1-2 minutter (17). Begge tiltak reduserte smerten signifikant sammenlignet med injeksjon på ubehandlet injeksjonssted, men Emla bare litt mer enn nedkjøling med is.

Det er publisert en rekke oppsummeringer av hvordan injeksjonssmerte kan reduseres. Én er ved Strazar og medarbeidere fra en avdeling med utstrakt bruk av lokalbedøvelse (4). Omkring 95\% av all håndkirurgi, også større inngrep som senetransposisjoner, forgår der i lokalbedøvelse. De bruker rutinemessig bufret lidokain med adrenalin. Adrenalintilsetning er trygt, også i fingre og tær (19). De har beskrevet sin prosedyre ved lokalbedøvelse som må anses som en gullstandard. $75 \%$ av pasientene kjenner kun det første stikket gjennom huden (4).

De bruker 30 gg kanyler i ansiktet, ellers 27 gg kanyler. Huden penetreres i $90^{\circ}$ vinkel, og kanylen føres gjennom huden til det subkutane fettlaget. Her injiseres $0,2-0,5 \mathrm{ml}$ lidokain mens sprøyten holdes i ro. Når pasientene angir at de ikke lenger kjenner kanylen, injiseres ytterligere $2 \mathrm{ml}$, hvoretter det injiserers til siden. Injeksjonen foregår sakte mens kanylen avanseres under huden. Det skal alltid være en 5-10 $\mathrm{mm}$ sone med hud foran sprøytespissen som er indurert av den injiserte væsken og avbleket av adrenalin. Dersom store områder skal bedøves, gjøres det nye stikk gjennom huden $10 \mathrm{~mm}$ innenfor kanten av det området med hud som er indurert og avbleket av adrenalin og dermed også bedøvet. I åpne sår injiserer de i selve såret, heller enn gjennom huden.

\section{Vilhjalmur Finsen (f. 1946)}

er spesialist i ortopedi og professor emeritus. Forfatter har fylt ut ICMJE-skjemaet og oppgir ingen interessekonflikter.
Litteratur

1. Skarsvåg TI, Wågø KJ, Tangen LF et al. Does adjusting the $\mathrm{pH}$ of lidocaine reduce pain during injection? J Plast Surg Hand Surg 2015; 49: 1-3.

2. Bartfield JM, Homer PJ, Ford DT et al. Buffered lidocaine as a local anesthetic: an investigation of shelf life. Ann Emerg Med 1992: 21: 16-9.

3. Hanna MN, Elhassan A, Veloso PM et al. Efficacy of bicarbonate in decreasing pain on intradermal injection of local anesthetics: a meta-analysis. Reg Anesth Pain Med 2009; 34: 122-5.

4. Strazar AR, Leynes PG, Lalonde DH. Minimizing the pain of local anesthesia injection. Plast Reconstr Surg 2013; 132: 675-84

5. Hogan ME, vanderVaart S, Perampaladas $\mathrm{K}$ et al. Systematic review and meta-analysis of the effect of warming local anesthetics on injection pain. Ann Emerg Med 2011; 58: 86-98.e1.

6. Lundbom JS, Tangen LF, Wågø KJ et al. The influence of Lidocaine temperature on pain during subcutaneous injection. J Plast Surg Hand Surg 2017 51: 118-21.

7. Powell MF. Stability of lidocaine in aqueous solu tion: effect of temperature, $\mathrm{pH}$, buffer, and metal ions on amide hydrolysis. Pharm Res 1987; 4: 42-5.

8. Johansen RB, Schafer NC, Brown PI. Effect of extreme temperatures on drugs for prehospital ACLS. Am J Emerg Med 1993; 11: 450-2.

9. Hamelin ND, St-Amand H, Lalonde DH et al. Decreasing the pain of finger block injection: level II evidence. Hand (NY) 2013; 8: 67-70.

10. Scarfone RJ, Jasani M, Gracely EJ. Pain of local anesthetics: rate of administration and buffering. Ann Emerg Med 1998; 31: 36-40.

11. Krause RS, Moscati R, Filice $M$ et al. The effect of injection speed on the pain of lidocaine infiltration. Acad Emerg Med 1997; 4: 1032-5

12. Tangen LF, Lundbom JS, Skarsvåg TI et al. The influence of injection speed on pain during injection of local anaesthetic. J Plast Surg Hand Surg 2016; 50: 7-9

13. Palmon SC, Lloyd AT, Kirsch JR. The effect of needle gauge and lidocaine $\mathrm{pH}$ on pain during intradermal injection. Anesth Analg 1998; 86: 379-81.

14. Watts AC, McEachan J. The use of a fine-gauge needle to reduce pain in open carpal tunnel decompression: a randomized controlled trial. J Hand Surg [Br] 2005: 30: 615-7.

15. Wågø KJ, Skarsvåg TI, Lundbom JS et al. The importance of needle gauge for pain during injection of lidocaine. J Plast Surg Hand Surg 2016; 50: $115-8$

16. Martires KJ, Malbasa CL, Bordeaux JS. A randomized controlled crossover trial: lidocaine injected at a 90-degree angle causes less pain than lidocaine injected at a 45-degree angle. J Am Acad Dermatol 2011: 65: 1231-3.

17. Kuwahara RT, Skinner RB. Emla versus ice as a topical anesthetic. Dermatol Surg 2001; 27: 495-6.

18. Leff DR, Nortley M, Dang V et al. The effect of local cooling on pain perception during infiltration of local anaesthetic agents, a prospective randomised controlled trial. Anaesthesia 2007; 62: 677-82.

19. Finsen V. Nekrose i fingre og tær etter lokalbed $\varnothing$ velse med adrenalin - en vandrehistorie? Tidsskr Nor Legeforen 2013; 133: 1827-30.

Mottatt 11.6. 2016, første revisjon innsendt 20.11 2016, godkjent 2.3. 2017. Redaktør: Inge Rasmus Groote. 